\title{
Method of transforming unauthorized dump into municipal solid waste landfill
}

\author{
Olga V. Atamanova ${ }^{1,{ }^{*}}$, Elena I.Tikhomirova ${ }^{1}$, Alexey $V$. Koshelev $^{1}$, Anton V. Aleksashin ${ }^{1}$, and Andrey L. Podolsky ${ }^{1}$ \\ ${ }^{1}$ Yuri Gagarin State Technical University of Saratov, 77 Polytekhnicheskaya St., Saratov, Russia
}

\begin{abstract}
We resolved the issue of eliminating unauthorized dumps of municipal solid waste (MSW). The MSW placement problem attracts special attention of the urban residents in the Russian Federation. However, the number of unauthorized MSW dumps in our country continues to increase. The accumulation of municipal waste in certain localities of urbanized centers, as well as in unauthorized dumps near residential areas is a serious problem for the environment and human health. MSW decomposition products lead to chemical, physical, and biological pollution of the lithosphere, hydrosphere and atmosphere. It is difficult to eliminate unauthorized dumps of municipal solid waste, since it is virtually impossible to have advance knowledge about the places of their formation. The objects of our investigation were MSW dumps. We conducted laboratory studies on the composition of wastewaters from the areas of unauthorized dumps within Saratov region, and discovered that precipitation-generated runoff from unauthorized dumps contained manifold excesses of toxic pollutants (heavy metals, organic matter, etc.). We proposed an original method for converting unauthorized dumps of solid household waste into the MSW landfills. The method includes two components: vertical planning of previously formed dump volume and annular surrounding drainage of the open type. The drainage ditch is connected to the water-collecting well, which is linked to the water storage tank joined, in its turn, to the water treatment plant.
\end{abstract}

\section{Introduction}

Currently, the problem of municipal solid waste (MSW) disposal and processing is among the most challenging global issues in the field of environmental protection. Goods that have lost their consumer properties over time and became garbage constitute the household waste. The amount of MSW in the Russian Federation is increasing annually by about $3 \%$ [1].

Prior to the $21^{\text {st }}$ century, the entire procedure of municipal waste disposal involved dumping of unnecessary materials into a landfill. People did not think about the harm done to the environment [2-3]. In recent decades, residents of the Russian Federation discovered there is too much space used for dumps, and that the garbage does not completely decompose [4]. When the state of environment significantly worsened, the country authorities began to think about possibility of recycling waste materials. To solve the problem of waste disposal, various institutions and organizations, designed for waste recycling and processing, emerged. Since the second half of the twentieth century, MSW landfills started to appear [5-10]. Currently, spontaneous unauthorized solid waste dumps are punishable by law and are subject to fines. However, the number of spontaneous dumps, due to such sanctions, did not decline. Dumping solid waste, which was the cheapest option, did not solve the problem because vapors and poisons were penetrating into soil with a subsequent poisoning effect [11-12]. For this reason, at present, many farmlands are experiencing the shortage of an arable land and pastures for the livestock. Wastewater from unauthorized dumps goes directly to the groundwater, poisoning it and nearby natural water bodies.

Unfortunately, people do not think that MSW, discarded at the wrong location, are a source of unpleasant odor, as well as food for most vertebrate carriers and invertebrate vectors of infectious diseases [13]. The problem of municipal solid waste disposal and utilization can be solved given the control over appropriate processing technology [14]. For greater convenience, separate collection of refuse has been adopted in foreign countries by using multiple containers for various waste varieties. In most civilized societies, manual or mechanical sorting of collected scrap materials is assumed. Due to such approach, it is possible to significantly reduce the amount of garbage taken to the landfill. The main issue of the competent MSW disposal is that the city authorities in most cities do not bother to solve the problem of MSW accumulation and processing. Many managers do not understand that the environmental situation in our country depends on solving this particular dilemma.

Accumulation of municipal waste at individual localities and unauthorized dumps is a serious environmental problem. An important issue is that unauthorized landfills, which appear in multiple

\footnotetext{
* Corresponding author: $\underline{\mathrm{O} V \text { Atamanova@mail.ru }}$
} 
locations of our urban and rural settlements, are rarely belong to the facilities in charge of servicing utilities, involved in the removal and disposal of solid waste [4]. MSW of unauthorized landfills include, for the most part, the remains of food products, packaging from previously purchased goods, leftovers of chemical products and substances, etc. All kinds of household waste can be conditionally divided into biological residues and non-biological waste, called garbage. Biological residues, which usually make up over $70 \%$ of the dump volume, do not pose a serious danger to the environment, because they fully decompose. However, they may not be dumped uncontrollably into garbage piles. Such dumps can become sources of infections, pathogenic bacteria and food supply for rats breeding rapidly in such favorable conditions. Food debris can become a trap for wildlife. The problem of MSW is especially relevant in the Russian Federation due to the lack of a science-based mechanism for their timely disposal and processing [2].

At present, despite environmentalists' call for solving the problem of unauthorized dumps, the number of such dumps within each residential area is increasing. The removal of MSW decomposition products from such dumps to the organized target landfills is not always economically viable for urban utilities [15]. Therefore, the authorities use one of the most environmentally unfriendly ways of destroying waste from unauthorized dumps via burning it. Moreover, there are types of refuse emitting poisonous gases. Of course, the volume of garbage per unit area decreases, while significant amount of toxic chemical compounds, such as dioxins, furans and biphenyls, is expelled into the air.

This fact accentuates the particular relevance of finding the solution to the problem of MSW disposal without dumping it.

\section{Objects and methods of research}

The objects of our investigation were MSW of unauthorized dumps.

Our study covered Saratov region and was aimed at creating MSW landfills for waste disposal in localities, where unauthorized dumps were formed. The results of our research can be used for safe MSW disposal, as well as for reduction of the negative impact of MSW on the natural ecosystems.

Within the framework of this study, we investigated the composition of precipitation-generated runoff waters from the area of unauthorized dumps. The major methods of our laboratory research included photometry, titration, and statistical data processing.

An analysis of existing methods used for sanitary conservation of MSW has revealed the method involving applying a protective layer of breathable material to the surface of solid household waste. Breathable material was made from uncontaminated dust of ferrous metallurgy waste and dolomite flour mixed in a ratio of 1:3. To enhance the biocidal effect of this material, highly effective preparation "Bio Z" was added to the mixture. The main methods for applying the protective layer of breathable material were the "thrusting" method and the "pushing" method [16]. The disadvantage of this method includes excessively high costs of transporting breathable material from the site of metallurgical production to the places of unauthorized dumps. In the Russian Federation, metallurgy is tied to a limited number of regions. In addition, this method does not presume dealing with discharge of rainwater runoff contaminated by the landfill products. Also, it does not provide any protection against the harmful wastewater effect on soil. In addition, the methods of "thrusting" and "pushing" would not allow for uniform distribution of breathable material over the surface of the landfill.

The problem is partially solved by the following method of waste disposal in the landfills. The method includes converting an unauthorized dump to a MSW landfill [17]. In this method, the upper parts of the previously formed dump volume and the surface of unauthorized dump are subjected to vertical planning. As a result of such planning work, the slope is created towards the cleared area. After that, a dam is erected along the lower contour of the planned cleared area. The height of the dam should be $0.5 \mathrm{~m}$ above the level of the technogenic aquifer inside the landfill. The dam is constructed from the soil of the cleared area. Then, an anti-filtration screen is constructed on the planned surface of the landfill and the cleared area, specifically, on the inner slope and the top of the dam. The antifiltration screen provides wastewater penetration into the ground. It is equipped with drainage pipes laid along the internal slope of the dam. The wellhead pipe connects the drainage pipes to an external reservoir for accumulation of the wastewater [17]. The disadvantage of this method is represented by the direct contact of the landfill volume with the base of the landfill, because if the groundwater level rises higher to the bottom of the landfill during the flood or high water period, this event could lead to contamination of the groundwater and soil with decomposition products originating from the dump. At such landfill, there is no system of periodic rinsing and disinfection of the landfill, which has a negative impact on the environment [18].

Studying and analyzing the existing methods for the MSW placement and disposal at unauthorized dumps gave us an urge to develop an original method for transforming unauthorized dump into the MSW landfill.

\section{Results and Discussion}

\subsection{The results of wastewater composition studies from the areas of unauthorized dumps}

The composition of wastewater runoff after the rainfall from the areas of unauthorized dumps is shown in Table 1. 
Table 1. Composition of wastewater runoff from unauthorized landfills (water samples were taken one hour after the rain).

\begin{tabular}{|c|c|c|c|c|}
\hline \multirow{2}{*}{$\begin{array}{c}\text { Pollutant or } \\
\text { physical } \\
\text { property }\end{array}$} & \multicolumn{4}{|c|}{ Location of dumps } \\
\hline & 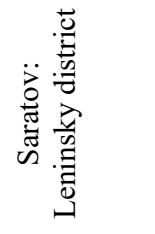 & 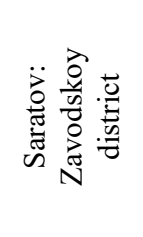 & 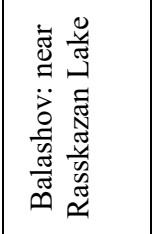 & 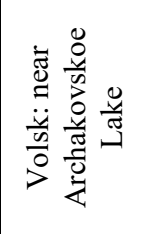 \\
\hline $\begin{array}{c}\mathrm{COD} \\
\left(\mathrm{mg} \mathrm{O}_{2} / \mathrm{dm}^{3}\right)\end{array}$ & $945 \pm 21$ & $1012 \pm 82$ & $730 \pm 46$ & $643 \pm 9$ \\
\hline $\begin{array}{c}\text { Smell at } \\
60^{\circ} \mathrm{C}, \\
\text { intensity } \\
\text { score }\end{array}$ & 3 & 3 & 4 & 5 \\
\hline $\begin{array}{l}\text { Chlorides } \\
\left(\mathrm{mg} / \mathrm{dm}^{3}\right)\end{array}$ & $667 \pm 7$ & $498 \pm 5$ & $728 \pm 11$ & $993 \pm 4$ \\
\hline $\begin{array}{l}\text { Sulphates } \\
\left(\mathrm{mg} / \mathrm{dm}^{3}\right)\end{array}$ & $1082 \pm 9$ & $962 \pm 18$ & $2078 \pm 33$ & $1021 \pm 73$ \\
\hline $\begin{array}{l}\text { Iron total } \\
\left(\mathrm{mg} / \mathrm{dm}^{3}\right)\end{array}$ & $21 \pm 1$ & $24 \pm 2$ & $18 \pm 2$ & $9 \pm 1$ \\
\hline $\begin{array}{c}\text { Copper } \\
\left(\mathrm{mg} / \mathrm{dm}^{3}\right)\end{array}$ & $1.24 \pm 0.02$ & $1.07 \pm 0.05$ & $0.60 \pm 0.05$ & $2.96 \pm 0.27$ \\
\hline $\begin{array}{c}\text { Zinc } \\
\left(\mathrm{mg} / \mathrm{dm}^{3}\right)\end{array}$ & $4.0 \pm 0.1$ & $5.50 \pm 0.03$ & $0.20 \pm 0.03$ & $2.3 \pm 0.1$ \\
\hline $\begin{array}{c}\text { Lead } \\
\left(\mathrm{mg} / \mathrm{dm}^{3}\right)\end{array}$ & $\begin{array}{c}0.020 \pm \\
0.005 \\
\end{array}$ & $\begin{array}{c}0.10 \pm \\
0.01 \\
\end{array}$ & $\begin{array}{c}0.050 \pm \\
0.001 \\
\end{array}$ & $\begin{array}{c}0.100 \pm \\
0.003 \\
\end{array}$ \\
\hline $\begin{array}{l}\text { Cadmium } \\
\left(\mathrm{mg} / \mathrm{dm}^{3}\right)\end{array}$ & $\begin{array}{c}0.0090 \pm \\
0.0007 \\
\end{array}$ & $\begin{array}{c}0.080 \pm \\
0.004\end{array}$ & $\begin{array}{c}0.030 \pm \\
0.002 \\
\end{array}$ & $\begin{array}{c}0.020 \pm \\
0.005\end{array}$ \\
\hline $\begin{array}{l}\text { Manganese } \\
\left(\mathrm{mg} / \mathrm{dm}^{3}\right)\end{array}$ & $0.9 \pm 0.1$ & $12.0 \pm 0.1$ & $5.1 \pm 0.2$ & $3.6 \pm 0.5$ \\
\hline $\begin{array}{l}\text { Phosphates } \\
\left(\mathrm{mg} / \mathrm{dm}^{3}\right)\end{array}$ & $43 \pm 1$ & $9 \pm 2$ & $32 \pm 4$ & $36 \pm 2$ \\
\hline $\begin{array}{c}\text { Carbon } \\
\text { disulphide } \\
\left(\mathrm{mg} / \mathrm{dm}^{3}\right) \\
\end{array}$ & $22 \pm 1$ & $8 \pm 1$ & $34 \pm 3$ & $2 \pm 1$ \\
\hline $\begin{array}{c}\text { Formaldehyde } \\
\left(\mathrm{mg} / \mathrm{dm}^{3}\right)\end{array}$ & $0.23 \pm 0.03$ & $1.05 \pm 0.04$ & $0.05 \pm 0.05$ & $1.46 \pm 0.25$ \\
\hline
\end{tabular}

Analysis of the data from Table 1 showed the excess of established standards for the pollutants in $94 \%$ of the cases. These pollutants poison the soil, groundwater, and open water bodies near each unauthorized dump.

\subsection{An original method of transforming an existing unauthorized dump into MSW landfill}

To increase the safety of MSW disposal and reduce its negative impact on the environment, we propose transforming existing unauthorized dumps into MSW landfills. Such reconstructed MSW landfill includes a hydraulic system for collecting and discharging contaminated filtration wastewaters, an engineering system for rinsing the landfill volume with disinfectant solutions. The reconstructed MSW landfill also includes protection of the landfill base from the penetration of contaminated solid waste with groundwater (for example, surficial water runoff in the spring, when the snow melts) [19].

The method of transforming unauthorized dump into the MSW landfill involves the vertical planning of a previously formed dump volume. We suggest constructing an open annular drainage with waterproof bottom, outer slope and the lower part of the inner slope of the drainage trenches, along the perimeter of the planned landfill (Fig. 1). The drainage trench at its lowest point of the bottom should be connected to the well designed to collect water. This well, in its turn, is connected to the water storage tank of the wastewater treatment plant. If the filtration coefficient of the natural soil at the base of the dump exceeds $10^{-8} \mathrm{~m} /$ day, the base of the future landfill should be made less waterpermeable. To implement this, we propose drilling horizontal boreholes $0.5 \mathrm{~L}$ long in the inner walls of the drainage trench (where $\mathrm{L}$ is the linear size of the landfill). A cement mortar is injected into the boreholes with the ratio of the cement mass to water varying from 0.1 to 2 . This ensures water resistance of the base soil and increases its strength. From above, the waste should be compacted, and the network of perforated plastic pipelines should be placed in it. The plastic should be resistant to temperature changes and chemically aggressive environments.

The MSW mound needs to be compacted in order to be waterproofed and covered with an outer soil layer. The system of perforated pipelines allows for the periodic supply of the special disinfectant or rinsing solutions to the landfill volume. The system of perforated pipelines collects and removes gaseous products from the landfill volume during the intervals between rinsing the pollutants. Those gaseous products are later removed from the landfill volume, which reduces the negative impact of MSW on the atmospheric air.

\section{Conclusions}

Using the proposed method of transforming unauthorized dump into the MSW landfill gives an opportunity:

- to liquidate uncontrolled dumping of MSW by converting it into an engineering structure (MSW landfill) without additional time and money expenditures; 

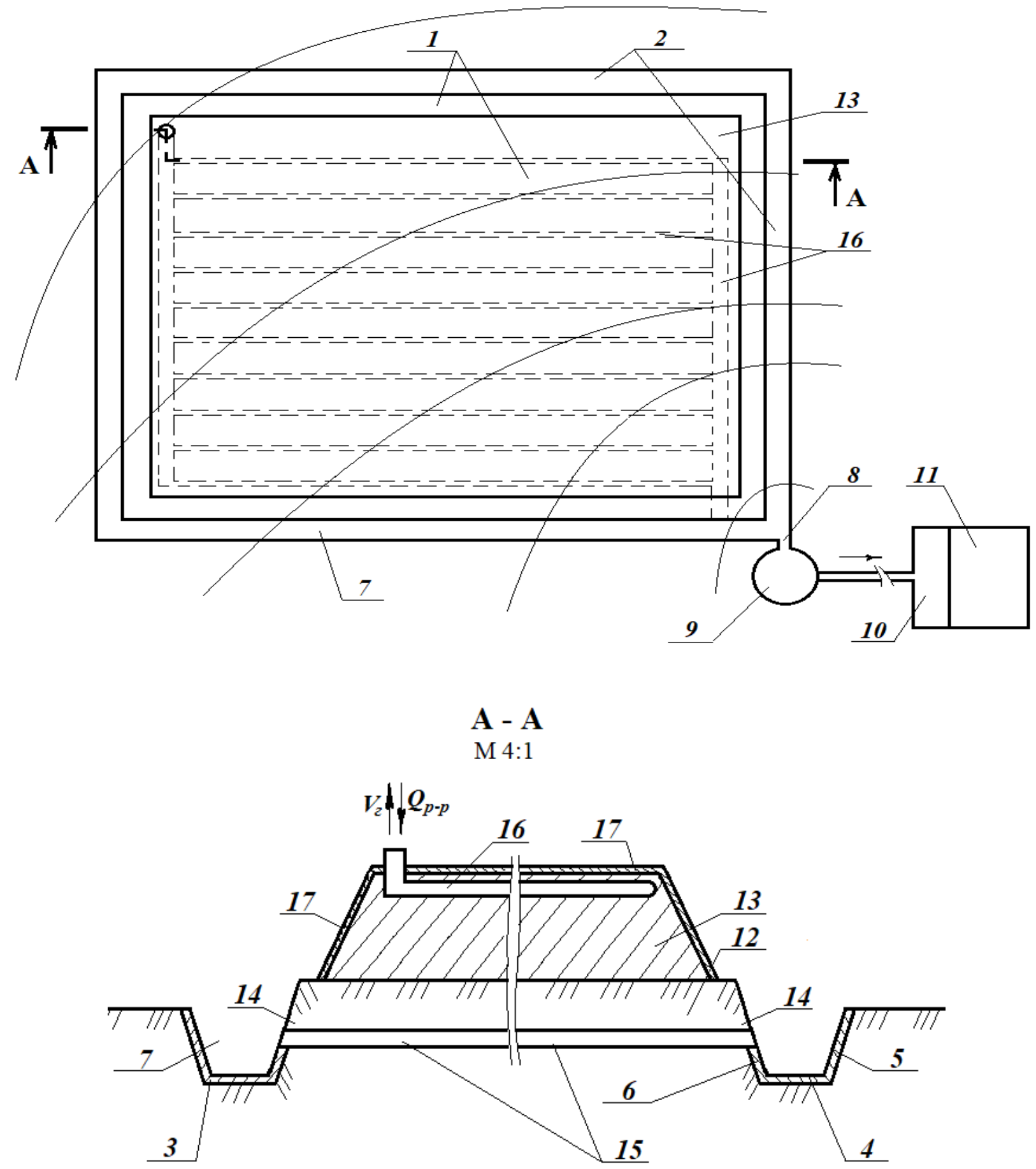

Fig. 1. The MSW landfill reconstructed from an unauthorized dump: 1 - dump volume; 2 - annular drainage of an open type; 3 waterproofing; 4 - bottom of the drainage trench; 5 - outer slope of the drainage trench; 6 - lower part of the drainage trench (inner slope); 7 - drainage trench; 8 - junction of the drainage trench with a well for collecting wastewater; 9 - well for collecting wastewater; 10 - water storage tank; 11 - water treatment station; 12 - landfill base; 13 - landfill; 14 - upper part of the inner wall of the drainage trench; 15 - the horizontal borehole; 16 - perforated pipe; 17 - bulk soil.

- to increase the engineering structure reliability by enhancing waterproof properties of the landfill base in order to secure the base from the negative impact of wastewater, thereby protecting the environment from their harmful effects;
- to provide rinsing of the landfill volume from the MSW decomposition products, minimizing their negative impact on the environment, with disinfectant solutions;

- to minimize the negative impact of toxic gases, generated in the MSW landfill and periodically released from it, on atmospheric air. 
The authors are grateful to the scientific-industrial enterprise LISSKON located in the city of Saratov, Russia, for participating in the discussion of the idea. The authors state no conflict of interests involved.

\section{References}

[1] S. Batar, T. Chandra, From Poverty, Inequality to Smart City, Conference paper, 20 December 2016, 3-18 (2017).

[2] V. Zamotaev, I.V. Ivanov, P.V. Mikheev, V.P. Belobrov, Eurasian Soil Science, 51, 827-842 (2018).

[3] V.M. Gilmundinov, T.O. Tagaeva, Regional Research of Russia, 9, 236-244 (2019).

[4] P. Baskakov, Thermal Engineering, 61, 265-273 (2014).

[5] M.D. Vaverkova, D. Adamcova, J. Zloch, M. Radziemska, A.B. Berg, S. Voběrkova, A. Maxianova, Journal of Ecological Engineering, 19, 4, 55-68 (2018).

[6] L. Fischer, U. Petschow, Municipal Waste Management in Europe, 5-62 (2000).

[7] D. Adamcova, M. Radziemska, A. Ridoškova, S. Bartoň, P. Pelcova, J. Elbl, J. Kynicky, M. Brtnicky, M.D. Vaverkova, Environmental assess-ment of the effects of a municipal landfill on thecontent and distribution of heavy metals in Tanacetum vulgare L., Chemosphere, 185, 10111018 (2017).

[8] H.A. van der Sloot, D.S. Kosson, A. van Zomeren, Waste Management, $\underline{\text { 63 }}$, 74-95 (2017).

[9] S. Melchior, Arbeitskreis Grundwasserschutz \& Süddeutsches Kunststoff-Zentrum (Hrsg.), Tagung "Die sichere Deponie", Würzburg, 33, 59 (2014).

[10] F.J. Los Barbosa, W.N. Schirmer, A.R. Cabral, M.A. Capanema,. The Journal of Solid Waste Technology and Management, 44, 3, 248-258 (2018).

[11] S. Xu, W. Lu,Y. Liu, Z. Ming, Y. Liu, R. Meng, H. Wang, Waste Management, $\underline{\mathbf{6 3}}, 41-48$ (2017).

[12] J. Bouma, Environmental Resource Management and the Nexus Approach, 179-209 (2016).

[13] S.-J. Feng, Q.-T. Zheng, H.X. Chen, Waste Management, 63, 107-121 (2017).

[14] T.C. Rees-White, J. Monster, R.P. Beaven, C. Scheutz, Waste Management, 87, 870-882 (2019).

[15] V.R. Polzer, K.M. Persson, The Open Waste Management Journal, 9, 1-10 (2016).

[16] Patent RU no. 2469805, B09 B1/00, no. 35 (2012) (in Rusian).

[17] Patent RU no. 2431530, B 09 B 1/0, no. 29 (2011) (in Rusian).

[18] I.S. Zen, Z.Z. Noor, R. O.Yusuf, Habitat International, 42, 83-89 (2014).
[19] Patent RU no. 2697095, B 09 B 1/0, no. 23 (2019) (in Rusian). 